\title{
Development of Peptidic Dopamine Transporter Inhibitors via Aromatic Modification Mediated Conformational Restriction
}

\author{
J inguo Ding, J iahao Shi, Dafu Cui, Linfeng Xu, Shuhui Duan, Lihe Guo, J ian FEI*
}

\section{Supporting Information}

Peptide synthesis. Solid-phase peptide synthesis was performed on an automated peptide synthesizer (Applied Biosystems, model 433A). The progress of chain assembly was monitored by quantitative ninhydrin test. 4-hydroxymethylphenoxymethyl-resin, 10 equivalents of Fmoc-amino acids and O-Benzotriazole $N, N, N$ ' $N$ '-tetramethyluro- niumhexafluoro-phosphate activation were employed. Amino acid derivatives, including Fmoc-4,4'-biphenylalanine-OH, Fmoc-1-naphthylalanine-OH, Fmoc-2-naphthylalanine-OH and Fmoc-4-benzoylphenylalanine-OH (Chem-Impex) were coupled with 4 equivalents. Isolation of peptides was achieved by stirring at room temperature in trifluoroacetic acid : $\mathrm{H}_{2} \mathrm{O}$ : p-cresol (94: $4: 2$ ) for $1 \mathrm{~h}$. Diethyl ether was added to precipitate the crude product, and reverse phase high performance liquid chromatography (HPLC) was performed on a Beckman C8 column to yield the pure peptides. Peptide 3 was transformed from H-Bip-Tyr(OBzl)-Thr-Pro-Lys-Thr-OH by trifluoroacetic acid (TFA). Chemical composition of the pure products was confirmed by LC/MS mass spectrometry (Applied Biosystems QTRAP). Anal. Calcd for peptide $1 \mathrm{C}_{46} \mathrm{H}_{62} \mathrm{~N}_{8} \mathrm{O}_{11}$ : C, 61.1; H, 6.9; N, 12.4. Found: C, 60.0; H, 6.6; N, 12.0. Anal. Calcd for peptide $5 \mathrm{C}_{52} \mathrm{H}_{60} \mathrm{~N}_{8} \mathrm{O}_{11}: \mathrm{C}, 63.8 ; \mathrm{H}, 6.8 ; \mathrm{N}, 11.4$. Found: $\mathrm{C}, 63.3 ; \mathrm{H}, 6.6 ; \mathrm{N}, 11.2$. Anal. Cal cd for peptide 11 $\mathrm{C}_{50} \mathrm{H}_{64} \mathrm{~N}_{8} \mathrm{O}_{11}: \mathrm{C}, 63.0 ; \mathrm{H}, 6.8 ; \mathrm{N}$, 11.8. Found: $\mathrm{C}, 62.8 ; \mathrm{H}, 6.6 ; \mathrm{N}$, 11.7. Anal. Calcd for peptide $13 \mathrm{C}_{46} \mathrm{H}_{54} \mathrm{~N}_{6} \mathrm{O}_{10}: \mathrm{C}, 65.0$; $\mathrm{H}, 6.4 ; \mathrm{N}, 9.9$. Found: $\mathrm{C}, 67.3 ; \mathrm{H}, 6.9 ; \mathrm{N}, 10.3$.

\begin{tabular}{crrrrrr}
\multicolumn{6}{l}{ LC/MS data for peptides } \\
\hline peptide & $\mathrm{tR}(\mathrm{min})^{\mathrm{a}}$ & $\begin{array}{r}\text { purity } \\
(\%)^{\mathrm{a}}\end{array}$ & $\mathrm{tR}(\mathrm{min})^{\mathrm{b}}$ & purity $(\%)^{\mathrm{b}}$ & MS calcd & $\begin{array}{r}\text { MS } \\
\text { found }\end{array}$ \\
$\mathbf{1}$ & 21.3 & $>98 \%$ & 13.9 & $>98 \%$ & 903.1 & 903.0 \\
$\mathbf{2}$ & 22.7 & $>98 \%$ & 16.4 & $>98 \%$ & 831.9 & 832.0 \\
$\mathbf{3}$ & 27.1 & $>98 \%$ & 21.3 & $>98 \%$ & 921.9 & 921.3 \\
$\mathbf{4}$ & 28.0 & $>98 \%$ & 25.3 & $>98 \%$ & 978.9 & 979.6 \\
$\mathbf{5}$ & 28.8 & $>98 \%$ & 26.5 & $>98 \%$ & 978.9 & 979.6 \\
$\mathbf{6}$ & 24.0 & $>98 \%$ & 18.6 & $>98 \%$ & 952.8 & 952.3 \\
$\mathbf{7}$ & 24.7 & $>98 \%$ & 19.1 & $>98 \%$ & 952.8 & 952.3 \\
$\mathbf{8}$ & 26.1 & $>98 \%$ & 20.0 & $>98 \%$ & 1006.9 & 1006.3 \\
$\mathbf{9}$ & 25.3 & $>98 \%$ & 19.9 & $>98 \%$ & 886.8 & 886.5 \\
$\mathbf{1 0}$ & 27.1 & $>98 \%$ & 20.9 & $>98 \%$ & 948.9 & 948.1 \\
$\mathbf{1 1}$ & 26.8 & $>98 \%$ & 20.2 & $>98 \%$ & 953.0 & 954.1 \\
$\mathbf{1 2}$ & 28.5 & $>98 \%$ & 25.7 & $>98 \%$ & 921.8 & 921.6 \\
$\mathbf{1 3}$ & 28.6 & $>98 \%$ & 26.2 & $>98 \%$ & 850.8 & 850.9 \\
$\mathbf{1 4}$ & 26.9 & $>98 \%$ & 20.4 & $>98 \%$ & 824.7 & 824.9 \\
$\mathbf{1 5}$ & 27.8 & $>98 \%$ & 25.0 & $>98 \%$ & 749.8 & 749.3 \\
\hline
\end{tabular}

${ }^{a} \mathrm{HPLC}$ was performed on a Beckman C8 column $(4.6 \times 250 \mathrm{~mm})$ at a flow rate of $1 \mathrm{ml} / \mathrm{min}$. The gradient was started at buffer A $(0.1 \%$ TFA in water) to $70 \%$ buffer B $(0.1 \%$ TFA in acetonitrile) in A in $50 \mathrm{~min}$. Percent purity was determined at $230 \mathrm{~nm}$. ${ }^{\circ} \mathrm{HPLC}$ was performed on a Zorbax Eclipse XDB-C8 column $(4.6 \times 150 \mathrm{~mm})$ at a flow rate of $1 \mathrm{ml} / \mathrm{min}$. The gradient was started at buffer A $(0.1 \%$ TFA in water) to $70 \%$ buffer B $(0.1 \%$ TFA in acetonitrile) in A in 70 min. Percent purity was determined at $230 \mathrm{~nm}$.

Circular Dichroism (CD). Peptides were dissolved in aqueous $20 \mathrm{mM}$ potassium phosphate, $40 \mathrm{mM} \mathrm{NaCl}, \mathrm{pH}$ 7 solution containing $10 \%$ trifluoroethanol to a concentration of $0.4 \mathrm{mg} / \mathrm{ml}$. CD spectra were obtained on a J asco J -715 spectropolarimeter at $20{ }^{\circ} \mathrm{C}$ using the following measurement parameters: wavelength, $190-250 \mathrm{~nm}$; sensitivity, 20 mdeg; step resolution, $0.1 \mathrm{~nm}$; scan speed, $10 \mathrm{~nm} / \mathrm{sec}$; accumulations, 1; response, $0.25 \mathrm{sec}$; bandwidth, $1 \mathrm{~nm}$; path length, $0.1 \mathrm{~cm}$.

${ }^{3} \mathbf{H}$-monoamine and ${ }^{3} \mathbf{H}-\bullet$-aminobutyric acid uptake experiments. Stable expressi on of rat DAT, rat SERT, rat NET and mouse GAT1 (•-aminobutyric acid transporter 1$)$ in $\mathrm{CHO}$ cells were carried out in our laboratory. In experiments examining dopamine uptake, CHO/rat DAT cells (D8 cells) were grown in RMPI 1640 medium containing 10\% FCS (Gibco BRL Life Technologies) to near confluence in 48-well tissue culture plates (Costar, approximately 60,000 cells per well). The culture medium was removed, and the cells were washed once with phosphate-buffered saline. Inhibitor drugs were preincubated with the cells in $90 \mu \mathrm{l}$ Hank's balanced salt solution for $10 \mathrm{~min}$ at $25{ }^{\circ} \mathrm{C}$ before the addition of ${ }^{3} \mathrm{H}$-dopamine (Amersham Biosciences, $5.8 \mathrm{Ci} / \mathrm{mmol}$ ), ascorbic acid and pargyline (to inhibit monoamine oxidase) at the final concentrations of $1 \mathrm{mCi} / \mathrm{l}, 100 \mu \mathrm{M}$ and $100 \mu \mathrm{M}$, respectively. The cells were incubated for $10 \mathrm{~min}$ at $25{ }^{\circ} \mathrm{C}$ in a final volume of $100 \mu \mathrm{l} \mathrm{Hank}$ 's balanced salt solution. Uptake was stopped by aspiration of the solution and the cells were washed three times rapidly (10 $\mathrm{sec} /$ wash) with ice-cold phosphate-buffered saline. Cells were then lysed in $0.5 \mathrm{M} \mathrm{KOH}$ for $20 \mathrm{~min}$ at room temperatures and the cell Iysate was counted by TRI-CARB 2900 TR liquid scintillation analyzer (Packard bioscience company) to quantify the uptake of ${ }^{3} \mathrm{H}$-dopamine. To observe the reversible inhibiting action of inhibitors, cells were rinsed with Hank's balanced salt solution twice after preincubation with inhibitor drugs and then ${ }^{3} \mathrm{H}$-dopamine added. Cells rinsed with Hank's balanced salt solution twice before preincubation with inhibitor drugs served as control. For dopamine saturation curve studies, increasing concentrations of non-labeled dopamine $(0-10 \mu \mathrm{M})$ were added immediately before ${ }^{3} \mathrm{H}$-dopamine. In experiments examining serotonin, norepinephrine and -aminobutyric acid uptake, the protocol was similar to that for dopamine 
transport assay. Nonspecific uptake of ${ }^{3} \mathrm{H}$-monoamine or ${ }^{3} \mathrm{H}$ - $\bullet$-aminobutyric acid was less than $2 \%$ of the total uptake defined by the isotope accumulation occurring in $\mathrm{CHO}$ cells. Peptides were dissolved in dimethylsulfone to concentration of $10 \mathrm{mg} / \mathrm{ml}$ and diluted by Hank's balanced salt solution to working concentration. Determinations were made in triplicate.

Radioligand binding assay. Binding assay was carried out on D8 cells using ${ }^{3} \mathrm{H}-\mathrm{CFT}[(-)-2-\bullet-c a r b o m e t h o x y-$ 3-•-(4-fluoropheneyl) tropane-1,5-naphthal enedisulfonate] (WIN 35, 428) (86 Ci/mmol, NEN) as radioligand. D8 cells were grown in RMPI 1640 medium containing 10\% FCS to near confluence in 48-well tissue culture plates. Binding assay was performed in a final volume of $100 \mu \mathrm{l}$ of Hank's balanced salt solution with $2 \mathrm{nM}$ labeled WIN35,428 plus increasing concentrations of peptide. Binding was terminated after $2 \mathrm{~h}$ at $4{ }^{\circ} \mathrm{C}$ by washing the cells three times with ice-cold phosphate-buffered saline. The cells were lysed in $0.5 \mathrm{M} \mathrm{KOH}$ and the cell lysate was taken for scintillation counting. Peptides were dissolved in dimethylsulfone to a concentration of $10 \mathrm{mg} / \mathrm{ml}$ and diluted with Hank's balanced salt solution to working concentration. Determinations were made in triplicate. Nonspecific binding represented $<\%$ of the total binding defined by the isotope adsorbance on $\mathrm{CHO}$ cells. Peptides were dissol ved in dimethylsulfone to concentration of $10 \mathrm{mg} / \mathrm{ml}$ and diluted by Hank's balanced salt solution to working concentration. Determinations were made in triplicate.

Behavioral testing. Male Bal b/c mice weighing $20-25 \mathrm{~g}$ were housed at $20 \pm 2{ }^{\circ} \mathrm{C}$ with a $12 / 12 \mathrm{~h}$ light/dark cycle (lights on at 7:00 a.m. and off at 7:00 p.m.), and allowed free access to food and water. Mice were single-housed $24 \mathrm{~h}$ before locomotor testing. Locomotor activity was assessed by recording the line breaks when mice were placed individually in $30 \times 25 \times 16.5 \mathrm{~cm}$ clear plastic cages with two lines located across the two axis, to which the mice had not been previously exposed. Under sound-attenuated conditions and soft light, line breaks was monitored by a video-tracking system for $2 \mathrm{~h}$. I mmediately after baseline activity testing, the mice were removed from the monitors, injected subcutaneously with saline, cocaine hydrochloride $(5 \mathrm{mg} / \mathrm{kg}$ ) peptides (20 or 10 $\mathrm{mg} / \mathrm{kg}$ ), and returned to the same chamber, where line breaks were monitored for an additional $4 \mathrm{~h}$. Reward was assessed by conditioned place preference testing using a two-compartment plastic chamber. One compartment $(25 \times 15 \times 12.5 \mathrm{~cm})$ had a yellow smooth floor and the other compartment $(25 \times 15 \times 12.5 \mathrm{~cm})$ had gray soft bathroom tissue bedding on the floor. A white $13 \times 4 \times 1.5 \mathrm{~cm}$ platform was flush with the wall dividing two sides, which were separated by a removable plastic wall. For pre-and post-conditioning test sessions, an opening in the center wall allowed access to both compartments. Locomotion and time spent in each compartment were recorded. During the conditioning sessions the opening was occluded to restrict mice to a single compartment. I nitial preference, usually for the bedding-floored compartment, was determined as the side in which a mouse spent more than 600 seconds of a 20 minutes trial in preconditioning phase. During conditioning session days, mice received a dose of either saline, cocaine hydrochloride $(10 \mathrm{mg} / \mathrm{kg})$, or peptides $(20 \mathrm{mg} / \mathrm{kg})$ subcutaneously and were restricted to one side of the compartment for $30 \mathrm{~min}$. Mice were returned to their home cages for $8 \mathrm{~h}$ and then given an injection of either drug or saline, whichever they had not yet received, and were placed in the opposite chamber for $30 \mathrm{~min}$. Pairing was randomized across groups and this process was repeated for 4 days. On day 5 a single conditioned place preference assessment session followed. Mice injected with saline were placed on the platform and the doors opened. The proportion of the 20-min session spent on each side was recorded. Results were compared with the proportion of time spent on that side in preconditioning sessions. Conditioned responses to saline, cocaine and peptides were assessed. Cocaine hydrochloride was dissolved in saline. The peptides were dissolved in $2.5 \%$ propylene $\mathrm{glycol} / \mathrm{saline}$ to the concentration of $1 \mathrm{mg} / \mathrm{ml}$ for injection.

Statistics and data analysis. Statistical calculations and comparisons were made using Origin 6.1 software (Northampton, MA, USA). Uptake and radioligand binding data were expressed as mean \pm s.e.m. of results obtained from 2 to 6 separate experiments in triplicate. Sigmoidal concentration-response curves for the calculation of $\mathrm{IC}_{50}, \mathrm{Km}$ or $\mathrm{Vmax}$ values were fit by non-linear regression. Behavioral data were analyzed by Student's test and analyses of variance. Data were presented as mean \pm s.e.m. for each experimental group and $\mathrm{P}<0.05$ was considered significant. 